\title{
Isolation and Partial Characterization of a D-Galactose- Binding Lectin from the Latex of Synadenium carinatum
}

\author{
Maria Aparecida Souza*, Francielle Amâncio-Pereira, Cristina Ribeiro Barros Cardoso, \\ Adriano Gomes da Silva, Edmar Gomes Silva, Lívia Resende Andrade, Janethe Deolina \\ Oliveira Pena, Henrique Lanza and Sandra Regina Afonso-Cardoso \\ Laboratório de Imunologia; Instituto de Ciências Biomédicas; Universidade Federal de Uberlândia; Av. Pará, \\ 1720; Bloco 4C; Campus Umuarama; 38400-902; Uberlândia - MG - Brasil
}

\begin{abstract}
A lectin from the latex of Synadenium carinatum was purified by affinity chromatography on immobilized-Dgalactose-agarose and shown to be a potent agglutinin of human erythrocytes. The haemagglutination of human red cells was inhibited by $3.0 \mathrm{mM} \mathrm{N}$-acetyl-D-galactopyranoside, $6.3 \mathrm{mM}$ methyl- $\beta$-D-galactopyranoside, $50 \mathrm{mM}$ methyl- $\alpha$-D-galactopyranoside and $50 \mathrm{mM} D$-fucose but not by L-fucose, demonstrating an anomeric and a conformational specificity. According to SDS-PAGE analysis, the lectin appeared to be a glycoprotein composed of two polypeptide chains of ca. 28 and $30 \mathrm{kDa}$, but size exclusion chromatography (Sephadex G-100) and native PAGE revealed a protein of apparent molecular weight $120-130 \mathrm{kDa}$ made up of 28 and $30 \mathrm{kDa}$ subunits. The lectin was stable in the range $\mathrm{pH} 6-9$, and $4-56^{\circ} \mathrm{C}$. The $\mathrm{N}$-terminal sequence of the $30 \mathrm{kDa}$ subunit contained the conserved consensus sequence GPN observed in other D-galactose-binding lectins found in latex of members of the Euphorbiaceae.
\end{abstract}

Key words: D-Galactose-binding, lectin, latex, Synadenium carinatum

\section{INTRODUCTION}

Lectins are a complex and heterogeneous group of proteins with diverse molecular structures, biochemical properties and carbohydrate-binding specificities (Licastro et al., 1993). They are widely distributed in nature, particularly in the plant kingdom where they can be found in seeds, leaves, bark, bulbs, rhizomes, roots, cotyledons and tubers (Cavada et al., 1998; Witisuwannakul et al., 1998; Yagi et al., 2002; Oliveira et al., 2002; Konozy et al., 2002, 2003). Seeds of leguminous species often contain large amounts of lectins that are similar to those present in other tissues of the same plant, including the latex.

Plant lectins have recently been defined to be plant proteins, possessing at least one non-catalytic domain, which bind reversibly to a specific monoor oligo-saccharide (Van Damme et al., 1998). Complex oligosaccharide structures present on the surface of cells, incorporated into the matrix and attached to secreted glycoproteins, can play structural roles, effect the movement of glycoconjugates to the cell surface or act as markers mediating cell-cell and cell-matrix recognition events (Dodd and Drickamer, 2001). By virtue of their binding capabilities, lectins are

\footnotetext{
*Author for correspondence
} 
thus involved in diverse mechanisms such as endocytosis, intracellular translocation of glycoproteins, cellular regulation, migration and adhesion, phagocytosis and the binding of microorganisms to host cells (Sharon and Lis, 1993).

Lectin specificity is usually defined according to the mono- or oligo-saccharide that is able to inhibit the agglutinating activity induced by the lectin. Many galactose-specific lectins have been isolated from plants. A particularly rich source of such lectins is the latex of members of the Euphorbiaceae, for example, Hura crepitans L., Euphorbia characias L. (Barbiere et al., 1983), E. marginata (Stirpe et al., 1993), E. neriifolia (Seshagirirao and Prasad, 1995), E. milii (DiasBaruffi et al., 2000), Hevea brasiliensis (Gidrol et al 1994; Witisuwannakul et al., 1998; Rojas et al., 2001), Synadenium grantii (Premaratna et al., 1981), and S. cupulare (Jager et al., 1996).

The plant Synadenium carinatum (Euphorbiaceae) is common in ornamental gardens in Brazil, and an aqueous preparation of the latex has been used in popular medicine to treat a number of diseases. In the present study, we describe the isolation and partial characterization of a D-galactose-binding lectin present in the aqueous extract of the latex of this species.

\section{MATERIALS AND METHODS}

\section{Extraction of latex protein}

Plants of $S$. carinatum were authenticated by $\mathrm{Dr}$ Glein Monteiro Araujo (Instituto de Biologia, Universidade Federal de Uberlândia, MG, Brazil) and a voucher specimen is located in the herbarium of this institution. Proteins were extracted from fresh latex by gentle shaking with deionised water, in the proportion $1: 5$, for $48 \mathrm{~h}$ at $4^{\circ} \mathrm{C}$. The mixture was centrifuged $\left(3500 \times \mathrm{x} g, 30 \mathrm{~min}, 4^{\circ} \mathrm{C}\right.$; Eppendorf centrifuge) and filtered through nitrocellulose membranes $(0.45 \mu \mathrm{m}$ pore size; Merck, Göttingen, Germany) to yield a crude extract. Protein concentration was determined according to the procedure of Lowry et al. (1951), and the extract was stored at $-20^{\circ} \mathrm{C}$ until required for assay.

\section{Haemagglutination assay}

Fresh human, mouse, rabbit, and horse erythrocytes were used in the initial haemagglutination assay. For all subsequent assays, human erythrocytes of type $\mathrm{A} \mathrm{Rh}^{+}(\mathrm{A}+)$ were employed. Following the approval of the Ethical Committee of the Universidade Federal de Uberlândia, (approval number 064/2001), erythrocytes were collected from healthy volunteers and separated from the platelet-rich plasma and buffy coat by differential centrifugation $\left(500 \mathrm{x} \mathrm{g}, 15 \mathrm{~min}, 25^{\circ} \mathrm{C}\right)$. Red cells were washed in $0.15 \mathrm{M} \mathrm{NaCl}$ and then recentrifuged $\left(1000 \mathrm{x} \mathrm{g}, 10 \mathrm{~min}, 25^{\circ} \mathrm{C}\right)$. The haemagglutination titre was assayed by preparing two-fold serial dilutions of the crude extract (1:2 to 1:1024) in V-well microtitre plates $(50 \mu \mathrm{l})$ and adding $25 \mu \mathrm{l}$ of a fresh erythrocyte suspension $(2 \%)$ in $0.15 \mathrm{M} \mathrm{NaCl}$. After $1 \mathrm{~h}$ at room temperature, when the erythrocytes had fully sedimented, each well was examined for agglutination. The haemagglutination titre was defined as the reciprocal of the largest dilution that was able to induce visible erythrocyte agglutination.

\section{Assay of inhibition of haemagglutination}

The inhibition assays were performed in a manner similar to the haemagglutination assays. The carbohydrates (Sigma, St Louis, MO, USA) methyl- $\alpha$-D-galacto-pyranoside, methyl- $\beta$-Dgalactopyranoside, N-acetyl-D-galacto-pyranoside, dextrose, D-galactose, D-mannose, D-glucose, Dfructose, L-sorbose, L-arabinose, melibiose, stachyose, methyl- $\alpha$-D-mannopyranoside, Lfucose, D-fucose, ribose, trehalose, $\alpha$-rhamnose, lactose, saccharose, maltose, D-raffinose and dextrose were employed as potential inhibitors. Serial two-fold dilutions of each carbohydrate were prepared in $0.15 \mathrm{M} \mathrm{NaCl}$ solution and mixed with equal volumes of extract containing 4 units of haemagglutinating activity. Mixtures were incubated for $30 \mathrm{~min}$ at room temperature, after which a suspension of human A+ erythrocytes (2\%) was added and the whole incubated for $1 \mathrm{~h}$. The lowest carbohydrate concentration that produced complete inhibition of haemagglutination was determined. 


\section{Gel filtration chromatography}

A sample of crude extract (20 mg) was applied at room temperature to a column $(85 \times 2.5 \mathrm{~cm}$ i.d. $)$ containing $450 \mathrm{ml}$ of Sephadex G-200 (Amersham Pharmacia Biotech, Uppsala, Sweden) in $0.02 \mathrm{M}$ Tris buffer at $\mathrm{pH} 7.2$ (TBS). The column was eluted with TBS at a flow rate of $0.285 \mathrm{ml} / \mathrm{min}$ and fractions were collected and monitored spectrophotometrically at $280 \mathrm{~nm}$. Fractions associated with each peak were pooled, concentrated, dialysed against water using Amicon YM 10kDa membrane (Millipore Corp., Belford, MA, USA) and then analysed by SDS-PAGE.

In order to determine the molecular weight of the lectin, size exclusion chromatography on a column (26 x $0.9 \mathrm{~cm}$ i.d.) of Sephadex G-100 (Amersham Pharmacia Biotech) was carried out. Purified lectin (2 mg) obtained by affinity chromatography (see below) was applied to the gel, which had previously been equilibrated with TBS at room temperature, and eluted at a flow rate of $0.16 \mathrm{ml} / \mathrm{min}$ : the collected fractions were monitored spectrophotometrically at $280 \mathrm{~nm}$.

\section{Affinity chromatography}

Galactose-binding lectin was purified on immobilised D-galactose-agarose (Pearce, Rockford, IL, USA) equilibrated with $0.05 \mathrm{M}$ borate buffer at $\mathrm{pH} 7.2$ (BBS). The lectin was eluted with $0.4 \mathrm{M}$ D-galactose in BBS (BBS-DGal): the effluent was pooled, concentrated and dialysed against TBS.

\section{Cation exchange chromatography}

The purified lectin $(2 \mathrm{mg} / \mathrm{ml})$ was subjected to cation exchange chromatography on a CMSepharose CL6B (Amersham Pharmacia Biotech) column equilibrated with $0.01 \mathrm{M}$ sodium acetate ( $\mathrm{pH}$ 5.0). After elution of the non-adsorbed proteins, a linear gradient of $\mathrm{NaCl}(0$ to $2 \mathrm{M})$ in sodium acetate buffer was applied and the effluent monitored spectrophotometrically at $280 \mathrm{~nm}$ : fractions collected were dialysed against TBS.

\section{Polyacrylamide gel electrophoresis}

Sodium dodecyl sulphate - polyacrylamide gel electrophoresis (SDS-PAGE) was carried out under denaturing conditions using 12 or $15 \%$ homogeneous polyacrylamide gels and the discontinuous Tris-glycine system of Laemmli
(1970). In addition, 8\% native PAGE was performed using Tris-glycine alkaline $(\mathrm{pH}$ 8.3) buffer (Davis, 1964). Proteins were visualised by silver staining (Heukeshoven and Dernick, 1988), and periodic acid-Schiff (PAS) staining reagent (Glossmann and Neville, 1971) was used to detect glycosidic linkages in glycoproteins. The molecular markers employed were phosphorylase B (97 kDa), bovine serum albumin $(66 \mathrm{kDa})$ ovalbumin (43 $\mathrm{kDa})$ carbonic anhydrase $(29 \mathrm{kDa})$ trypsin inhibitor $(18 \mathrm{kDa})$, lysozyme $(14 \mathrm{kDa})$, aprotinin $(6.3 \mathrm{kDa})$, and insulin (b) chain (3.4 kDa), all from Amersham Pharmacia Biotech.

\section{Red blood cells overlay assay}

Following separation by $15 \%$ SDS-PAGE, proteins on the gel were electro-transferred onto ImmobilonNC (Millipore) nitrocellulose transfer membranes using a semi-dry system (Amersham Pharmacia Biotech) operating at $0.8 \mathrm{~mA} / \mathrm{cm}^{2}$ for $2 \mathrm{~h}$. The membrane was incubated in TBS containing $1 \%$ Triton X-100 for $1 \mathrm{~h}$ at room temperature, washed three times with TBS and subsequently incubated with TBS containing $1 \%$ bovine serum albumin (TBS-BSA) for $1 \mathrm{~h}$ at room temperature. The membrane was then incubated with a human erythrocyte suspension (2\%) in TBS-BSA for $1 \mathrm{~h}$ at room temperature with gentle shaking. After washing, the membrane was fixed for $10 \mathrm{~min}$ in $3 \%$ buffered formalin in TBS.

\section{Effect of temperature and pH on haemagglutination}

The influence of temperature on the haemagglutinating activity of the lectin was determined by incubation of aliquots of the purified protein at $4,25,37,56$ and $95^{\circ} \mathrm{C}$ for 30 min prior to assay. The $\mathrm{pH}$ sensitivity of the lectin was established by incubating aliquots of the purified protein for $1 \mathrm{~h}$ in buffers at $\mathrm{pH}$ values 3-12: the haemagglutinating activity of the lectin was then measured after adjusting the $\mathrm{pH}$ of the assay solution to 7.0

\section{Analytical isoelectric focusing (IEF)}

The $\mathrm{pI}$ of the lectin was evaluated using pre-cast polyacrylamide gels (PhastGel, Pharmacia, Uppsala, Sweden) in the $\mathrm{pH}$ range 3-9. The $\mathrm{pH}$ gradient in the gels was determined from simultaneous runs performed with a wide-range 
isoelectric-focusing protein calibration kit (Pharmalyte 3-9, Pharmacia).

\section{Sequencing N-terminal amino acids}

A sample of the affinity-purified lectin was run on a 15\% SDS-PAGE under denaturing, but not reducing, conditions and transferred to a PVDF membrane (Bio-Rad, Hercules, CA, USA). The blot was stained with Coomassie Brilliant Blue and the $30 \mathrm{kDa}$ band was submitted to N-terminal sequencing by the Edman degradation method in an automatic sequencer model ABI 477A (Amersham Pharmacia Biotech, Freiburg, Germany). Sequence homologies were searched within an on-line protein database (http://srs.ebi.ac.uk).

\section{Cytotoxicity assay}

In order to determine if the crude latex extract or the isolated lectin exhibited cytotoxic activity, an assay was performed using J774.A1 cells and peritoneal murine macrophages. Peritoneal exudate cells (PEC) from BALB/c mice, previously inoculated with $3 \%$ sodium thioglycolate medium, were harvest with RPMI-1640 medium. PEC were seeded at $4 \times 10^{6}$ cells/well into 24 well tissue culture plates and incubated in $5 \% \mathrm{CO}_{2}$ for $2 \mathrm{~h}$ at $37^{\circ} \mathrm{C}$. Non-adherent cells were removed by washing vigorously with RPMI-1640 medium. Adherent cells were incubated in $1 \mathrm{ml}$ of RPMI-1640 medium supplemented with $10 \%$ foetal bovine serum (Cultilab, Campinas, Brazil), $100 \mathrm{U} / \mathrm{ml}$ penicillin, $100 \mu \mathrm{g} / \mathrm{ml}$ streptomycin and $2 \mathrm{mM} \mathrm{L}-$ glutamine (Sigma), in the presence or absence of Escherichia coli lipopolysaccharide (Sigma) (10 $\mu \mathrm{g} / \mathrm{ml})$, or crude latex extract or purified lectin (1, $2,5,10,20,30,50,100$ or $200 \mu \mathrm{g} / \mathrm{ml})$. After incubation for 24,48 and $72 \mathrm{~h}$ in $5 \% \mathrm{CO}_{2}$ in a humidified chamber at $37^{\circ} \mathrm{C}$, cells were collected and their viabilities determined by Trypan Blue exclusion (Sigma).

\section{RESULTS}

\section{Analysis of the crude extract}

The crude extract of the latex of $S$. carinatum agglutinated all human blood groups and erythrocytes from rabbit and mouse, but not from horse (Table 1), revealing the presence of a lectin that was subsequently named ScLL. The crude extract was separated into five fractions on Sephadex G-200 (Fig. 1) each of which was subjected to SDS-PAGE and assayed for haemagglutinating activity. The protein profile revealed on the gel (Fig. 1 insert; lanes 1-5) was compatible with that exhibited by gel filtration, but only the fraction associated with the third peak showed haemagglutinating activity (Fig. 1; blocked triangles) against human $\mathrm{A}+$ erythrocytes with a titre of 16 .

Table 1 - Haemagglutination assay

\begin{tabular}{lcccc}
\hline \multirow{2}{*}{\multicolumn{1}{c}{ Erythrocytes }} & \multicolumn{2}{c}{ Crude extract } & Lectin ScLL \\
\cline { 2 - 5 } & Titre & $\begin{array}{c}\text { Concentration } \\
(\mu \mathrm{g} / \mathbf{m l}))^{\mathbf{a}}\end{array}$ & Titre & Concentration $(\mu \mathrm{g} / \mathbf{m l})$ \\
\hline Human type A+ erythrocytes & 128 & 23.4 & 320 & 3.0 \\
Human type B+ erythrocytes & 128 & 23.4 & 320 & 3.0 \\
Human type AB+ erythrocytes & 64 & 46.9 & ND & ND \\
Human type O+ erythrocytes & 128 & 23.4 & 320 & 3.0 \\
Rabbit erythrocytes & 64 & 46.9 & 16 & 62.5 \\
Mouse erythrocytes & 32 & 93.7 & 8 & 125 \\
Horse erythrocytes & $\mathrm{NH}^{\mathrm{c}}$ & & $\mathrm{NH}$ & \\
\hline
\end{tabular}

${ }^{\mathrm{a}} \mathrm{\mu g} / \mathrm{ml}$ of the protein; ${ }^{\mathrm{b}} \mathrm{ND}$ - assay not performed; ${ }^{\mathrm{N} H}$ - no haemagglutination observed

\section{Assay of inhibition of haemagglutination}

The level of inhibition by various carbohydrates of the haemagglutinating activity against human A+ erythrocytes was assessed in order to determine the carbohydrate-affinity of the lectin. It was observed that carbohydrates containing a D-galactose radical were able to bring about total inhibition of haemagglutination (Table 2). 


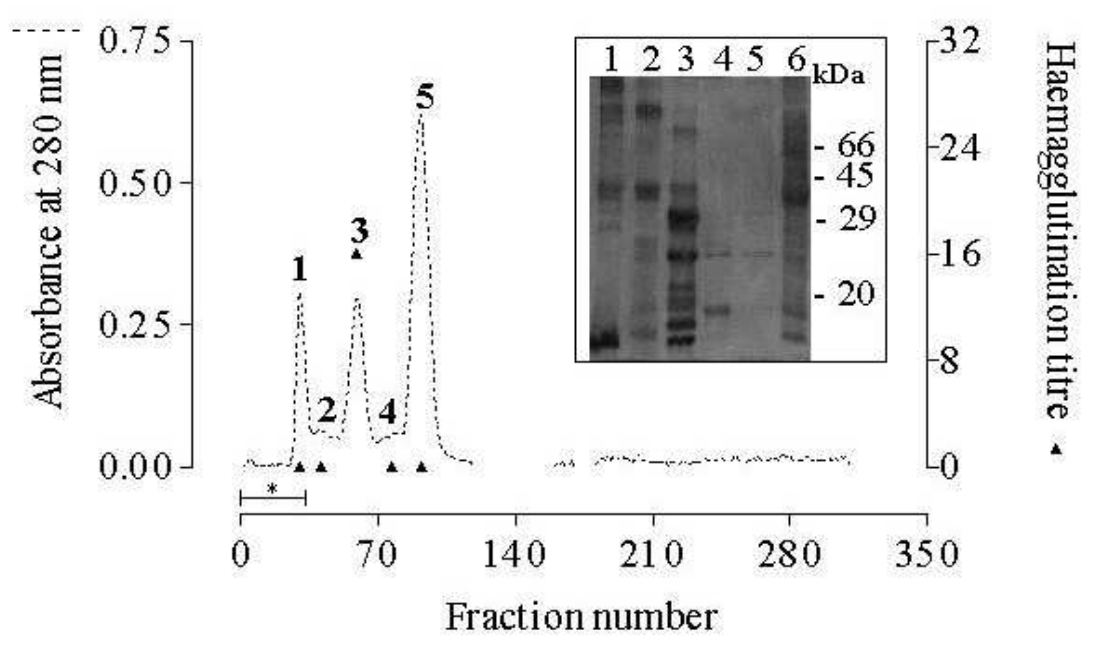

Figure 1 - Gel filtration (Sephadex G-200) chromatogram of an aqueous extract of the latex of Synadenium carinatum and the haemagglutination titres of the components. The eluted fractions were collected (fraction size $-2 \mathrm{ml}$; flow rate $-0.5 \mathrm{ml} / \mathrm{min}$ ) and monitored spectrophotometrically at $280 \mathrm{~nm}$ (----); the asterisk corresponds to the void volume of the column. For each peak, fractions with the highest absorbance values were analysed for haemagglutinating activity $(\boldsymbol{\Delta})$. The insert shows the electrophoretic profiles $(12 \%$ SDS-PAGE; proteins visualised by silver stain) of the five eluted peaks: lanes 1-5 correspond to peaks 1-5, respectively, in the chromatogram, whilst lane 6 corresponds to the original crude aqueous extract.

Table 2 - Carbohydrate-specificity of a crude aqueous extract of the latex of Synadenium carinatum $^{\text {a }}$

\begin{tabular}{|c|c|}
\hline Carbohydrate & Inhibition $(\mathrm{mM})^{\mathrm{b}}$ \\
\hline Methyl- $\alpha$-D-galactopyranoside & 50.0 \\
\hline Methyl- $\beta$-D-galactopyranoside & 6.3 \\
\hline N-acetyl-D-galactopyranoside & 3.0 \\
\hline Methyl- $\alpha$ - D-mannopyranoside & $\mathrm{NI}^{\mathrm{c}}$ \\
\hline Stachyose & NI \\
\hline L-Fucose & NI \\
\hline D-Fucose & 50.0 \\
\hline Ribose & $\mathrm{NI}$ \\
\hline Trehalose & NI \\
\hline$\alpha$-Rhamnose & NI \\
\hline D-Glucose & NI \\
\hline D-Mannose & NI \\
\hline D-Fructose & NI \\
\hline D-Galactose & 6.3 \\
\hline L-Arabinose & NI \\
\hline L-Sorbose & $\mathrm{NI}$ \\
\hline Melibiose & 6.3 \\
\hline Lactose & 12.5 \\
\hline Saccharose & NI \\
\hline D-Raffinose & 12.5 \\
\hline Maltose & NI \\
\hline Dextrose & $\mathrm{NI}$ \\
\hline
\end{tabular}


Thus activity was completely eliminated by $\mathrm{N}$ acetyl-D-galacto-pyranoside and methyl- $\beta$-Dgalacto-pyranoside at 3.0 and $6.3 \mathrm{mM}$, respectively, and by methyl- $\alpha$-D-galactopyranoside and D-fucose at a somewhat higher concentration $(50.0 \mathrm{mM})$. No inhibition by Lfucose was observed even at $100 \mathrm{mM}$.

\section{Affinity chromatography analysis}

The crude extract was applied to an immobilized D- galactose-agarose column and the electrophoretic profiles and the haemagglutinating activities of the fractions were determined. The protein fraction that bound to D-galactose (labelled 3 in Fig. 2) presented a high haemagglutination titre (320) and, according to SDS-PAGE, was composed of two subunits, one with a molecular weight of $28 \mathrm{kDa}$ and another of $30 \mathrm{kDa}$ (Fig. 2 insert; lane 3). Staining with PAS reagent (Fig. 2 insert, lane 4) indicated that the $30 \mathrm{kDa}$ polypeptide was glycosylated. The protein fraction labelled $\mathbf{2}$ in
Fig. 2 (corresponding to lane 2 in the insert) did not bind to D-galactose and no agglutination activity was observed.

\section{Overlay analysis}

In order to examine which of the two subunits possessed haemagglutinating activity, a blood cell overlay assay was performed. Samples of the crude extract of the latex were separated by SDS-PAGE, electro-blotted onto a nitro-cellulose sheet and incubated with human A+ erythrocytes. Erythrocyte binding was observed to be associated only with the $30 \mathrm{kDa}$ band (Fig. 3, lane 1). In addition, when the nitrocellulose membrane was pre-incubated with D-galactose in order to inhibit haemagglutinating activity, no erythrocyte binding could be observed (Fig. 3, lane 2).

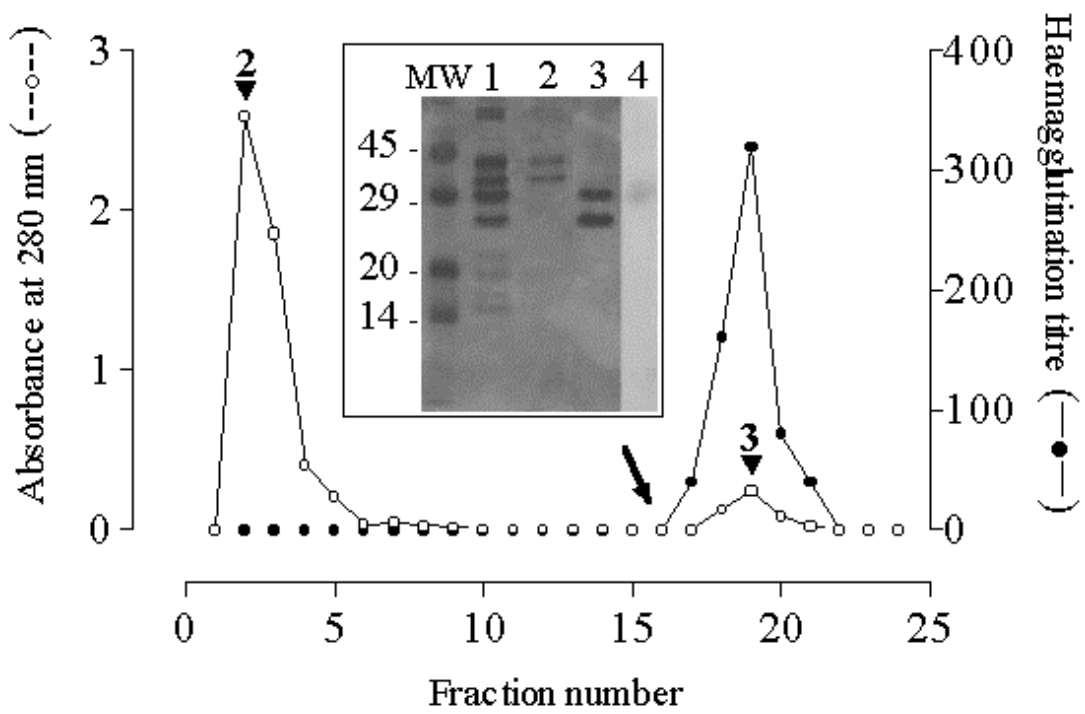

Figure 2 - D-galactose-affinity chromatogram of the crude aqueous extract of the latex of Synadenium carinatum. A sample $(2 \mathrm{mg}$ ) was applied to $3 \mathrm{ml}$ of immobilised Dgalactose- agarose, previously equilibrated with BBS, and eluted initially with BBS followed by BBS-D-Gal (changeover indicated by an arrow): eluted fractions were collected (fraction size - $2 \mathrm{ml}$; flow rate - $1 \mathrm{ml} / \mathrm{min}$ ), monitored spectrophotometrically at $280 \mathrm{~nm}$ (--0--) and assayed for haemagglutinating activity (-- --). Peaks labelled 2 and 3 correspond to the elution of non-bound and bound proteins, respectively. The insert shows the electrophoretic profiles (15\% SDSPAGE; proteins visualised by silver stain unless otherwise stated) of the eluted peaks: lane 1 - original crude aqueous extract, lane 2 - D-Gal non-bound fraction, lane 3 ScLL, lane 4 - ScLL visualised with PAS, and lane MW - molecular weight markers. 


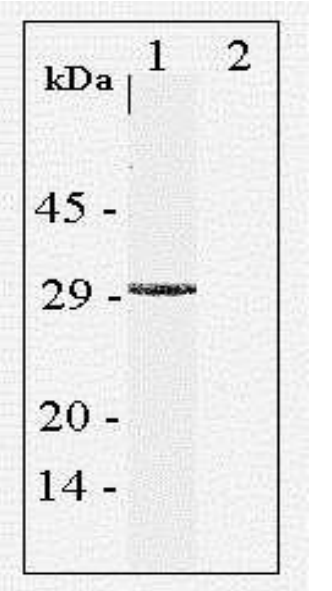

Figure 3 - Erythrocytes overlay. Lane 1 shows the result of electro-transferring the gel after 15\% SDS-PAGE separation of the original crude aqueous extract of the latex of Synadenium carinatum onto a nitrocellulose membrane and then incubating with human type A+ erythrocytes (see Materials and Methods). Lane 2 shows exactly the same experiment conducted using a nitrocellulose membrane which had been preincubated with D-galactose.

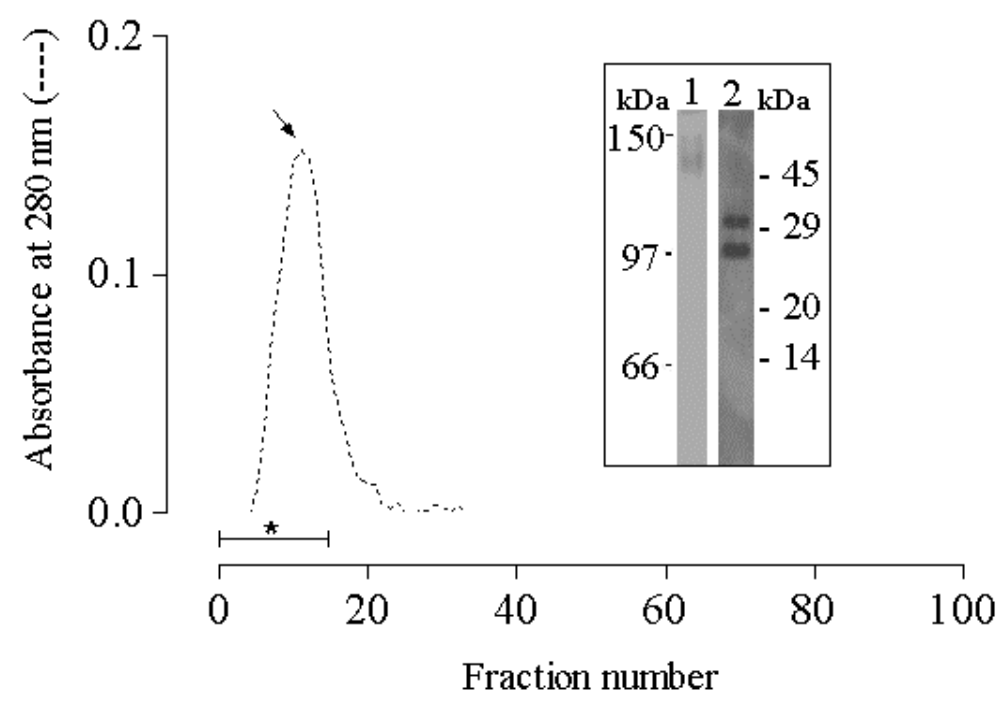

Figure 4 - Size exclusion gel filtration chromatogram of ScLL. In order to estimate the molecular weight of the lectin, a sample $(2 \mathrm{mg}$ ) of the purified protein was applied to a Sephadex G-100 column, previously equilibrated with TBS, and eluted with TBS. The eluted fractions were collected (fraction size $-0.5 \mathrm{ml}$; flow rate $-0.16 \mathrm{ml} / \mathrm{min}$ ) and monitored spectrophotometrically at $280 \mathrm{~nm}(----)$; the asterisk corresponds to the void volume of the column. The insert shows the electrophoretic profiles of the fraction indicated by an arrow on native PAGE (lane 1) and on SDS-PAGE (lane 2). 
Determination of the native molecular weight of the lectin

Following size exclusion chromatography over Sephadex G-100, the lectin fraction was obtained as a single peak (arrowed in Fig. 4) within the void volume (indicated by an asterisk) signifying that the lectin possessed a molecular mass $>100 \mathrm{kDa}$. This fraction showed a single band with an apparent molecular weight of 120-130 kDa when analysed by native PAGE (Fig. 4 insert, lane 1). In contrast, SDS-PAGE of the fraction showed two bands with apparent molecular weights of 28 and $30 \mathrm{kDa}$ (Fig. 4 insert, lane 2).

\section{Ion exchange chromatography and pI}

The determined pI value of 4.4 (Fig. 5 insert) was in agreement with the observation that when the lectin was buffered with $0.05 \mathrm{M}$ sodium acetate (pH 5.0) and loaded onto a CM-cellulose column, it was fully adsorbed and eluted as a single peak with $0.77 \mathrm{M} \mathrm{NaCl}$ (Fig. 5).

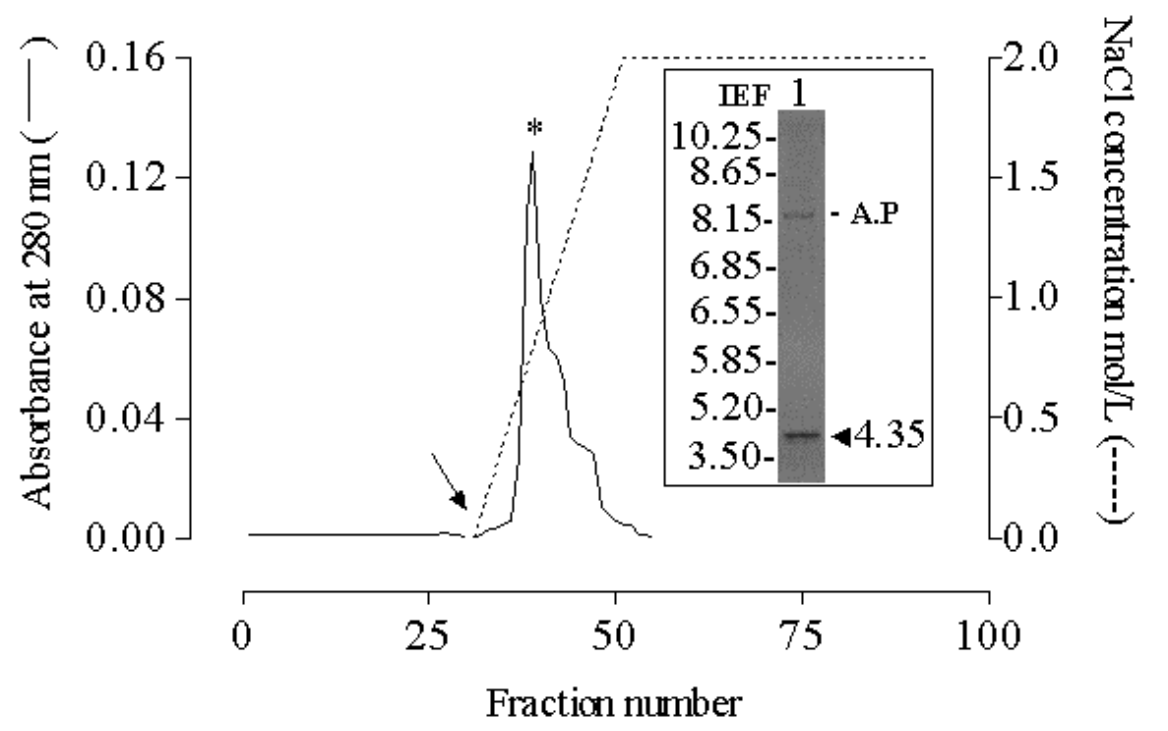

\begin{abstract}
Figure 5 - Cation exchange chromatogram of ScLL and determination of pI. An aliquot $(2 \mathrm{ml})$ of ScLL solution $(1 \mathrm{mg} / \mathrm{ml})$ was applied to a CM-Sepharose DEAE column $(20 \mathrm{ml})$ that had been pre-equilibrated with $0.01 \mathrm{M}$ sodium acetate buffer $(\mathrm{pH}$ 5.0). The column was eluted with the same buffer to elute the non-bound proteins, and then (changeover indicated by an arrow) with a continuous gradient of $\mathrm{NaCl}$ in this buffer (----) to elute the bound proteins. The eluted fractions were collected (fraction size $1.5 \mathrm{ml}$; flow rate $-0.562 \mathrm{ml} / \mathrm{min}$ ) and monitored spectrophotometrically at $280 \mathrm{~nm}$ ). The insert shows the isoelectric focusing (IEF) gel of the fraction indicated by an asterisk with the arrowhead indicating the pI of ScLL and the label A.P indicating the loading point.
\end{abstract}

\section{Effect of pH and temperature}

Thermal denaturation experiments revealed that the lectin remained stable below $56^{\circ} \mathrm{C}$ for more $30 \mathrm{~min}$ with no loss of haemagglutinating activity. At $95^{\circ} \mathrm{C}$, ScLL lost its activity completely within $30 \mathrm{~min}$ (Fig. $6 \mathrm{~A})$. Whilst the lectin retained its haemagglutinating activity within the $\mathrm{pH}$ range 6.0-9.0 (Fig. 6B), it was sensitive to very acidic $(\mathrm{pH} 3.0)$ and to very basic $(\mathrm{pH}$ 12.0) conditions, under which the activity was completely lost.

\section{$\mathbf{N}$-terminal sequence}

The nine amino acid $\mathrm{N}$-terminal sequence of the 30 $\mathrm{kDa}$ band of ScLL was determined using the Edman degradation method (Table 3). The GPN consensus sequence was homologous to two other lectins derived from Euphorbiaceae species, both of which showed affinity for D-galactose.

\section{Analysis of cytotoxic activity}

No cytotoxic effects of ScLL, or of the crude latex extract, in concentrations ranging from 1 to 200 
$\mu \mathrm{g} / \mathrm{ml}$ were observed with $\mathrm{J} 774$ cells or with (data not shown). peritoneal murine macrophages within 24 to $72 \mathrm{~h}$

Table 3 - N-terminal sequences of D-galactose-binding lectins isolated from members of the Euphorbiaceae

\begin{tabular}{llllllllllllllllllll}
\hline Species & \multicolumn{10}{c}{ Sequence } & Reference / subunit \\
\hline Euphorbia characias & S & E & S & Y & T & P & I & S & G & P & N & G & Y & X & V & D & V & K & {$[21]$} \\
Euphorbia marginata & A & Y & P & G & S & H & I & S & G & P & N & G & F & X & M & D & V & K & [21] \\
Synadenium carinatum & - & L & Y & T & S & I & I & . & G & P & N & & & & & & 30 kDa band of ScLL \\
\hline
\end{tabular}
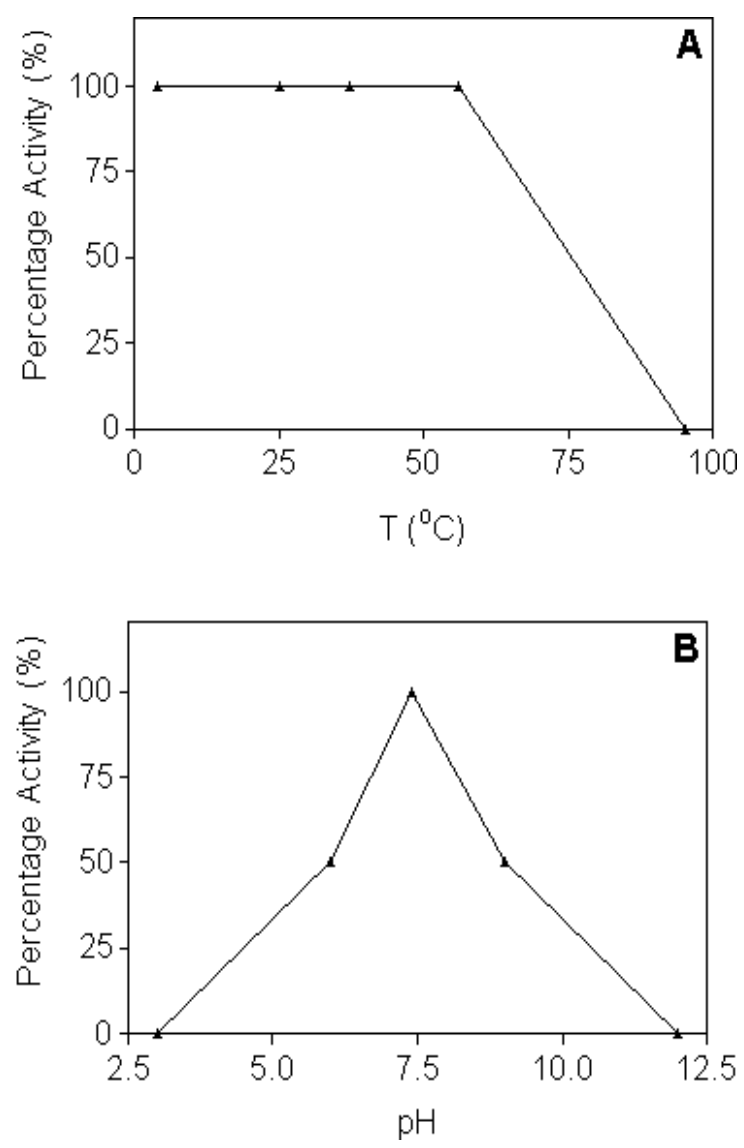

Figure 6 - Effects of $\mathrm{pH}(\mathrm{A})$ and temperature (B) on the haemagglutinating activity of ScLL. The percentage activity was calculated assuming that the maximum measured activity was $100 \%$.

\section{DISCUSSION}

Although the latex of $S$. carinatum has been used extensively in the treatment of various diseases, it is actually very toxic to humans. For this reason an analysis of the components of the latex is central to the elucidation of the risks associated with the ingestion of this material. It has recently been shown by sequential extraction with methanol, dichloromethane and hexane followed by thin layer chromatographic analysis (Souza et al., 2000) that flavonol glucosides and lupeol are present in the latex. In the present study, a D-galactose-binding lectin (named ScLL) was isolated from the latex of $S$. carinatum and partially characterized. An aqueous extract was employed for two reasons: (i) 
a water solution of the latex of this plant has been used in popular medicine, and (ii) an aqueous solution of the latex is stable and the lectin properties are not lost.

Purified ScLL exhibited strong agglutination of different species of erythrocytes, however, the titre against human type A+ erythrocytes was 20 - and 40 -fold higher than against rabbit or mouse red blood cells, respectively. In contrast, no agglutination of horse erythrocytes was observed. These findings could be explained by differences in glycosylation of the surface proteins of red blood cells in the species tested.

It is interesting to note that treatment with SDS did not influence the binding of the lectin to red blood cells. The agglutinating activity was, however, completely inhibited by D-galactose, as has been reported for other lectins derived from the Euphorbiaceae (Stirpe et al., 1993). Although a number of D-Gal-binding lectins exhibited preferential haemagglutinating activity against human A, B and O blood groups (Datta et al., 1988; Witisuwannakul et al., 1998; Machuka et al., 1999), ScLL showed no such specificity.

Methyl- $\alpha$ - and methyl- $\beta$-D-galacto-pyranoside inhibited haemagglutinating activity of ScLL to a different extent suggesting that the lectin differentiated between $\alpha_{-}$and $\beta$-galactose. Moreover, $\alpha$-rhamnose, L-arabinose and L-fucose did not inhibit agglutination whilst D-fucose did, suggesting that the configuration of the anomeric galactose residue had a significant effect on binding to ScLL. The higher binding capability of $\beta$-Dgalactopyranoside compared with free $\mathrm{D}$-galactose indicated a preference of the lectin for the $\beta$-Dpyranose form, which was predominantly in the ${ }^{4} \mathrm{C}_{1}$ chain conformation (Yeasmin et al., 2001; Kenoth et al., 2003). The lectin PSA isolated from Polyporus squamosus also exhibited an anomeric preference for the beta configuration (Mo et al., 2000).

Staining with PAS reagent, which detected glycosidic linkages, revealed that ScLL was a glycoprotein and the intact molecular weight of the lectin was determined as $c a$. 120-130 kDa by size exclusion gel filtration on Sephadex G-100 and native PAGE. These results clearly indicated that the intact lectin was a tetrameric glycoprotein with a quaternary structure based on four heterogeneous subunits of 28 and $30 \mathrm{kDa}$, as revealed by SDS-
PAGE. Most lectins have molecular weights in the range $26-400 \mathrm{kDa}$ and consisted of 2-18 homogeneous or heterogeneous subunits (Castagna et al., 1996; Machuka et al., 1999; Yeasmin et al., 2001). Galactose-specific lectins isolated from other plants have been reported to be dimeric or tetrameric proteins (Calvete et al., 1998; Machuka et al., 1999; Campana et al., 2002; Jung et al., 2003).

The $30 \mathrm{kDa}$ subunit of ScLL showed N-terminal homology with D-galactose-binding lectins from $E$. marginata and E. characias that have been reported as strong mitogenics for human $\mathrm{T}$ lymphocytes (Stirpe et al., 1993). The three lectins exhibited a three amino acid (GPN) domain in common with the D-galactose-binding lectin from Maclura pomifera (Osage orange) (Young et al., 1989). The acidic pI value of ScLL was typical of many galactose-specific lectins, for example, those from Erythrina species (Bhattacharyya et al., 1986; Konozy et al., 2002, 2003), Maclura pomifera, Sophora japonica (Hankins et al., 1988), and Luetzelburgia auriculata (Oliveira et al., 2002).

Although plant latex is often cytotoxic, neither the crude aqueous extract nor the purified lectin from the latex of $S$. carinatum showed any cytotoxic activity against $\mathrm{J} 774$ cells or murine peritoneal macrophages. It seemed that aqueous extraction was efficient for the separation of non-toxic proteins from the potentially toxic components present in the latex of S. carinatum.

The isolation and characterisation of the lectin described in the present work could permit further advances to be made in the clarification of the biological effects of lectins on human cells and on the activation of the immune system .

\section{ACKNOWLEDGEMENTS}

This work was supported in part by grants from the Programa de Pós-Graduação em Imunologia e Parasitologia Aplicadas (PPIPA), Instituto de Ciências Biomédicas, Universidade Federal de Uberlândia (ICBIM/UFU). The authors wish to thank Dr. Roque-Barreira for help in performing the $\mathrm{pI}$ analyses. 


\section{RESUMO}

No presente trabalho, foi purificada por cromatografia de afinidade em D-galactose imobilizada em agarose, uma lectina do latex de Synadenium carinatum (ScLL). Essa lectina é uma potente aglutinina para eritrócitos humanos, cuja atividade hemaglutinante foi inibida com $3,0 \mathrm{mM}$ de $\mathrm{N}$ acetil-D-galactopiranosidio, $6,3 \mathrm{mM}$ de metil$\beta$-D-galactopiranosidio ou $50 \mathrm{mM}$ metil- $\alpha$ - $D$ pironosidio ou D-fucose, porém, nenhuma inibição foi evidenciada por L-fucose, revelando uma especificidade anomérica e conformacional da lectina. A análise por SDS-PAGE dessa lectina pareceu ser uma glicoproteína composta por duas cadeias polipeptídicas de aproximadamente 28 e 30 $\mathrm{kDa}$, porém, em cromatografia de exclusão por tamanho sobre Sephadex G100 e em gel nativo apresentou um peso molecular aparente de 120-130 $\mathrm{kDa}$, a qual mostrou ser composta de uma mistura de subunidades de peptídeos de 28 e 30 $\mathrm{kDa}$. Essa lectina manteve-se estável em $\mathrm{pH}$ de 6 a 9 e temperatura de 4 a $56^{\circ} \mathrm{C}$. A sequiência $\mathrm{N}$ terninal contem uma região conservada GPN a qual também é observada em outras lectinas de látex de outras Euphorbiaceas ligante de Dgalactose.

\section{REFERENCES}

Barbiere, L.; Falasca, A.; Franceshi, C.; Licastro, F.; Rossi, C. A. and Stirpe, F. (1983), Purification and propeties of two lectins from latex of the euphorbiaceous plants Hura crepitans L. (sand-box tree) and Euphorbia characias L. (Mediterranean spurge). Biochem. J., 215, 433-439.

Bhattacharyya, L.; Ghosh, A. and Sen, A. (1986) A comparative study on lectins from four Erythrina species. Phytochemstry, 25, 2117-2122.

Calvete, J. J.; Santos, C. F.; Mann, K.; Grangeiro, T. B.; Nimtz, M.; Urbanke, C. and Sousa-Cavada, B. (1998), Amino acid sequence, glycan structure, and proteolytic processing of the lectin of Votairea macrocarpa seeds. FEBS Letters, 425, 286-292.

Campana, P. T.; Moraes, D. I.; Monteiro-Moreira, A. C. O. and Beltramini, L. M. (2002), Unfolding and refolding studies of frutalin, a tetrameric D-galactose binding lectin. Eur. J. Biochem., 269, 753-758.
Castagna, L.; Zarzur, J.; Filipetti, M. and Landa, C. (1996), Isolation and partial characterization of $\mathrm{N}$-acetyl-D-galactosamine-binding lectins from Epiphragmophora trenquelleonis snail. J. Biochem., 119, 372-377.

Cavada, B. S.; Santos, C. F.; Grangeiro, T. B.; Nunes, E. P.; Sales, P. V. P.; Ramos, R. L.; De Souza, F. A. M.; Crisostomo, C. V. and Calvete, J. J. (1998), Purification and characterization of a lectin from seeds of Vatairea macrocarpa Duke. Phytochemistry, 49, 675-680.

Datta, P. K.; Basu, P. S. and Datta, T. K. (1988), Purification of human erythrocytes specific lectins from rice bean, Phaseolus calcaratus syn, by highperformance liquid chromatography. J. Chromatogr., 431, 37-44.

Davis, B. J. (1964), Disc electrophoresis II, methods and application to human serum proteins. Ann. N. Y. Acad. Sci., 121, 404-427.

Dias-Baruffi, M.; Sakamoto, M.; Rosseto, S.; VozariHampe, M. M. and Roque-Barreira, M. C. (2000), Neutrophil migration and aggregation induced by euphorbin, a lectin from the latex of Euphorbia milii, var. milii. Inflamm. Res., 49, 732-736.

Dodd, R. B. and Drickamer, K. (2001), Lectin-like proteins in model organisms: implications for evolution of carbohydrate-binding activity. Glycobiology, 11, 71R-79R.

Gidrol, X.; Chrestin, H.; Tan, H. L. and Kush, A. (1994), Hevein, a lectin-like protein from Hevea brasiliensis (rubber tree) involved in the coagulation of latex. J. Biol. Chem., 269, 9278-9283.

Glossmann, H. and Neville Jr., D. M. (1971) Glycoproteins of cell surfaces. Comparative study of three different cell surfaces of the rat. J. Biol. Chem., 246, 6339-6346.

Hankins, C. N.; Kindinger, J. I. and Shannon, L. M. (1988), The lectins of Sophora japonica. 2. Purification, properties, and N-terminal amino acid sequences of 5 lectins from bark. Plant Physiol., 86, 67-80.

Heukeshoven, J. and Dernick, R. (1988), Improved silver staining procedure for fast staining in PhasSystem development unit. I. Staining of sodium dodecyl sulphate gels. Electrophoresis, 9, 28-32.

Jager, A.; Hutchings, A. and Van Staden, J. (1996), Screening of Zulu medicinal plants for prostaglandin-synthesis inhibitors. $J$. Ethnopharmacol., 52, 95-100.

Jung, W. K.; Park, P. J. and Kim, S. K. (2003), Purification and characterization of a new lectin from the hard roe of skipjack tuna, Katsuwonus pelamis, Int. J. Biochem and Cell Biol., 35, 255-265. 
Kenoth, R.; Komath, S. S. and Swamy, M. J. (2003), Physicochemical and saccharide-binding studies on the galactose specific seed lectin from Trichosanthes cucumerina. Arch Biochem. Biophys, 413, 131-138.

Konozy, E. H. E.; Bernardes, E. S.; Rosa, C.; Faca, V.; Greene, L. J. and Ward, R. J. (2003), Isolation, purification and physicochemical characterization of a D-galactose-binding lectin from seeds of Erythrina speciosa. Arch. Biochem. Biophys., 410, 222-229.

Konozy, E. H. E.; Mulay, R.; Faca, V.; Ward, R. J.; Greene, L. J.; Roque-Barreira, M. C.; Sabharwal, S. and Bhide, S. V. (2002), Purification, some properties of a D-galactose-binding leaf lectin from Erythrina indica and further characterization of seed lectin. Biochimie, 84, 1035-1043.

Laemmili, U. K. (1970) Cleavage of structural proteins during the assembly of the head of bacteriophage T4. Nature, 227, 680-685.

Liscastro, F.; Davis, L. J. and Morini, M. C. (1993), Lectins and superantigens: membrane interactions of these with $\mathrm{T}$ lymphocytes affect immune responses. Int. J. Biochem., 25, 845-852.

Lowry, O. H.; Rosebrough, A. L.; Farr, A. L. and Randall, R. J. (1951) Protein measurement with the folin-phenol reagent. J. Biol. Chem., 193, 165-275.

Machuka, J. S.; Okeola, O. G.; Van Damme, E. J. M.; Chrispeels, M. J.; Van Leuven, F. and Peumans, W. J. (1999), Isolation, and partial characterisation of galactose-specific lectins from African yam beans, Sphenostyles stenocarpa Harms. Phytochemistry, 51, 721-728.

Mo, H.; Winter, H. C. and Goldstein, I. J. (2000), Purification and characterization of a Neu5Aco2$6 \mathrm{Gal} / \mathrm{1} 1-4 \mathrm{Glc} / \mathrm{GlcNac}$-specific lectin from the fruiting body of the polypore mushroom Polyporus saquamosus. J.Biol. Chem., 275, 10623-10629.

Oliveira, J. T. A.; Melo, V. M. M.; Câmara, M. F. L.; Vasconcelos, I. M.; Beltramini, L. M.; Machado, O. L. T.; Gomes, V. M.; Pereira, S. P.; Fernandes, C. F.; Nunes, E. P.; Capistrano, G. G. G. and MonteiroMoreira, A. C. O. (2002), Purification and physicochemical characterization of a cotyledonary lectin from Luetzelburgia auriculata. Phytochemstry, 61, 301-310.

Premaratna, A.; Shadaksharaswamy, M. and Nanjappa, S. (1981) Isolation, purification and properties of a lectin from the latex of Synadenium grantii Hook f. Indian J. Biochem Biophys, 18, 3235.

Rojas, E.; Llinas, P.; Rodriguea-Romero, A.; Hernandez, C.; Linares, M.; Zanteno, E. and Lascurain, R. (2001), Havein, an Allergenic lectin from rubber latex, activates human neutrophils oxidadtive burst. Glycoconj. J., 18, 339-345.
Seshagirirao, K. and Prasad, M. N. (1995), Purification and partial characterization of a lectin from uphorbia neriifolia latex. Biochem. Mol. Biol. Int., 35, 1199-1204.

Sharon, N. and Lis, H. (1993), Carbhydrates in cell recognition. Sci. Am., 268, 82-89.

Souza, C. P.; Modesto, M. M. and Alves, T. M. A. (2000) Estudo químico da caramboleira e da leiterinha. FESB - O jovem e a ciência no futuro Abstract 15.P.7. Disp. in: [http://www.fesbe.org.br/ra/ fesbe2000/ojcf.html.

Stirpe, F.; Licastro. F.; Morini, M. C.; Parente, A.; Savino, G.; Abbondanza, A.; Bolognesi, A.; Falasca, A. I. and Rossi, C. A. (1993), Purification and partial characterization of mitogenic lectin from the latex of Euphorbia marginata. Biochem. Biophys. Acta, 1158, 33-39.

Van Damme, E. J. M.; Peumans, W. J.; Barre, A. and Rougé, P. (1998), Plant lectin: A composite of several distinct families of structurally and evolutionary related proteins with diverse biological roles. Cri. Rev. Plant Sci., 17, 575-692.

Witisuwannakul, R.; Witisuwannakul, D. and Sakulborirug, C. (1998), A lectin from bark of the rubber tree (Hevea brasiliensis). Phytochemstry, 47, 183-187.

Yagi, F.; Iwaya, T.; Haraguch, T. and Goldstein, I. J. (2002), The lectin from leaves of japanese cycad, Cycas revoluta Thunb. (gymnosperm) is a member of the jacalin-related family. Eur. J. Biochem, 269, 4335-4341.

Yeasmin, T.; Tang, M. A. K.; Razzaque, A. and Absar, N. (2001), Purification and characterization of galactose specific lectins from Mulberry seeds (Morus sp.). Eur. J. Biochem., 268, 6005-6010.

Young, N. M.; Johnston, R. A.; Szabo, A. G. and Watson, D. C. (1989), Homology of the D-galacotsespecific lectins from Artocarpus integrifolia and Maclura pomifera and the role of an unusual small polypeptide subunit. Arch. Biochem. Biophys, 270, 596-603.

Received: February 19, 2004; Revised: August 16, 2004; Accepted: March 11, 2005. 